\title{
ALTERNATIVES TO "PARENTAL RIGHT" IN CHILD CUSTODY DISPUTES INVOLVING THIRD PARTIES*
}

IN primitive societies, where the large kinship group is the basic societal unit, problems concerning child custody are solved by leaving the child with the dominant clan. ${ }^{1}$ In American society, the social mores do not provide an automatic answer to custody questions. ${ }^{2}$ When a dispute concerning the custody of a child can not be amicably settled, its resolution has been left to the courts. ${ }^{3}$ One major class of these disputes arises when the parents contest custody of their child attendant to a divorce or separation; the other, when a biological parent sues to regain custody of his child from some third party, often a relative. ${ }^{4}$ In every custody dispute societal interest in a successful personality development by the child and adult desires for the gratifications

*Root v, Allen, 377 P.2d 117 (Colo. 1962).

1. If an immediate family is dissolved by death, divorce or separation, the children remain in the clan in which they have been raised. In a matrilinear society the mother's clan is dominant, and upon dissolution of the family the children remain with that clan; the same pattern exists in patrilinear societies. In a bi-linear society established custom and rules dictate the automatic allocation of custody. Because the child has related primarily to the clan, the dissolution of the family has little impact upon him. Davis, Sociological and Statistical Analysis, 10 Law \& Contemr. Prob. 700, 701-04 (1944). See Lemkin, Orphans of Living Parents: A Comparative Legal and Sociological View, 10 LAW \& Contenrp. Prob. 834, 835 (1944).

2. Since our society is not based on the kinship group, but on the nuclear family, it lacks the societal institutions by which automatic allocations of custody can be made. See Davis, supra note 1, at 705. A suggested solution would be for our society to develop new institutional relationships to replace those of the kinship society. Id. at 720 .

3. The origin of the law's role in deciding custody disputes is usually traced to the concept of parens patriae and the duty of the court to protect the child who is unable to protect himself. See, e.g., Wilson v. Mitchell, 48 Colo. 454, 465, 111 Pac. 21, 25 (1910); Eyre v. Countess of Shaftsbury, 2 P. Wms. 103, 118, 24 Eng. Rep. 659, 664 (Ch. 1722); 4 U. PrTr. L. REv. 302 (1938). It has also been suggested that custody law stems from the feudal concept of the child as a chattel, who represented important monetary interests. Sayre, Awarding Custody of Children, 9 U. CHI. L. Rev. 672, 675 (1942).

In any event, the jurisdiction of equity, and later, law over child custody disputes was well established in England by the 18th century. See, e.g., Eyre v. Countess of Shaftsbury, supra; Ex parte Hopkins, 3 P. Wms. 152, 24 Eng. Rep. 1009 (Ch. 1732) ; Blissets Case, Lofft 748, 98 Eng. Rep. 899 (K.B. 1774).

4. The divorce or separation custody dispute, while usually arising during or immediately following the dispute between parents, is also liable to future litigation under the doctrine of "changed circumstances." See, e.g., Coulter v. Coulter, 141 Colo. 237, 347 P.2d 492 (1959); Maupin v. Matupin, 339 IIl. App. 484, 90 N.E.2d 234 (1950). The third party dispute most often arises following the death of the parent who had custody of the child, when the third party-usually a step-parent, grandparent, or close relative-assumes custody of the child. At this point, the living biological parent requests that the child be delivered to him, the third party refuses, and the parent institutes court proceedings to gain custody. See, e.g., Root v. Allen, 377 P.2d 117 (Colo. 1962) ; Zeigler v. Dusto, 103 Kan. 901, 176 Pac. 974 (1918). 
and challenges of parenthood may be in conflict. ${ }^{5}$ In order to focus best upon court concern for the child, this Note will limit itself to questions of third party custody disputes, as offering the greatest opportunity for separation of parentoriented from child-oriented factors in custody dispositions.

The life-history of Sharon, the eleven year old subject of the custody dispute in a recent Colorado case, Root $v$. Allen, ${ }^{6}$ is similar to that of many children involved in third party cases. When Sharon was in her first year, her parents were divorced; Sharon and her mother Rachel, who obtained custody by agreement, then moved to Denver. Here Rachel met and, after two years, married Robert Allen. Three years later Mr. and Mrs. Allen separated for some ten months, during which time Mr. Allen visited Sharon several times every week. Mr. and Mrs. Allen were reconciled, but, when Sharon was eight years old, her mother died. For a year and a half before his remarriage, Mr. Allen was the sole parental figure in her life. Meanwhile, Sharon's biological father, William Root, had remarried and had established a home in California. In the ten years following his divorce, he had seen Sharon only once, for a period of an hour and a half, when he was introduced as a friend of the family. ${ }^{7}$ But when, following his wife's death, Mr. Allen asked Mr. Root for permission formally to adopt Sharon, Mr. Root refused and instituted a habeas corpus proceeding to obtain custody of Sharon. The trial court awarded custody to Mr. Allen, and, in a strongly worded opinion, the Supreme Court of Colorado affirmed. The court indicated unequivocally that the doctrine of "parental right" had long been abandoned, and that any presumption in favor of the natural parent which might exist under a "best interest" test was rebuttable and had, in fact, been rebutted in this case..$^{8}$

The "parental right" and "best interest of the child" tests considered by the Colorado court are the two leading doctrines used in third party custody disputes. ${ }^{9}$ The minority doctrine of parental right holds that a biological parent

5. This possibility has been recognized by several commentators. See, e.g., Comment, 33 CALIF. L. REv. 306, 310, 316 (1945).

6. 377 P.2d 117 (Colo. 1962).

7. At the trial Mr. Root stated that he had refrained from communicating with Sharon in an effort to allow her to have a normal family life. Id. at 119; Record, ff. 120-23, 138-42.

8. 377 P.2d at $120-21$.

9. A possible third doctrine that is occasionally applied to third party custody disputes is a balancing test in which the rights of the biological parent, the rights of the third party, and the interests of the child are weighed together. Since this test usually places heaviest weight on the welfare of the child, it may be no more than a restatement of the best interest test. See Chapsky v. Wood, 26 Kan. 650 (1881).

The parental right and best interest doctrines are often confused to some extent in the opinions. See Bradley v. Bennett, 168 Ala. 240, 53 So. 262 (1910); Adair v. Clure, 218 Iowa 482, 255 N.W. 658 (1934); Chapsky v. Wood, supra. Furthermore, in several of the states both major doctrines seem to exist side by side with the courts utilizing first one and then the other. Compare Brown v. DeWitt, 320 Mich. 156, 30 N.W.2d 818 (1948), with 20 Mich. Stat. Ann. \$ 27.3178 (1962). See generally 7 ARk. L. Rev. 405 (1953). It has been suggested that this seeming interchangeability of the doctrines is due to the fact that they seek the same basic objective from two sides. Johnstone, Child Custody, 1 Kan. L. REv. 37, $42-44$ (1952). 
is entitled to custody of the child unless he is affirmatively shown to be unfit. ${ }^{10}$ Unfitness may be demonstrated by evidence that the child had been abandoned by the natural parent, or that the moral character of the natural parent is unsatisfactory, or that the home environment offered by the natural parent is unsuitable. ${ }^{11}$ Despite the ambiguity in the terms "unfitness," "abandonment," "unsatisfactory," and "unsuitable,"12 most courts using the parental right doctrine consider the test limited in its field of inquiry and relatively simple in its application to particular fact situations. ${ }^{13}$ On the other hand, the courts which use the more prevalent best interest test operate in a comparatively free-wheeling manner. ${ }^{14}$ In determining best interest courts evaluate any of a large number of factors including moral fitness of the competing parties; the comparative physical environments offered by the parties; the emotional ties of the child to the parties and of the parties to the child; the age, sex and health of the child; the desirability of maintaining continuity of the existing relationships between the child and the third party; and the articulated preference of the child. ${ }^{15}$ The multiplicity and complexity of these

10. E.g., Roche v. Roche, 25 Cal. 2d. 141, 152 P.2d 999 (1944); Stout v. Stout, 166 Kan. 459, 201 P.2d 637 (1949) ; Ex parte Barnes, 54 Ore. 548, 104 Pac. 296 (1909); ILt. Rev. STAT. ch. 3, § 132 (1961).

11. See, e.g., Bradley v. Bennett, 168 Ala. 240, 53 So. 262 (1910) (moral character of father); Schroeder v. Filbert, 41 Neb. 745, 60 N.W. 89 (1894) (abandonment by father); Ex parte Adams, 67 Okla. 96, 168 Pac. 1004 (1917) (moral character of father); 6 A.s. Code Mo. art. 72A, § 1 (1957) (abandonment by parents). An attempt to list all the criteria of fitness in some order of importance is rarely made by the courts. The various commentators, however, have assidiously performed this task. See, e.g., Johnstone, supra note 9, at 45-47 (1952). For a strict view of the criteria of fitness see Taylor v. Taylor, 182 Okla. 11, 15-16, 75 P.2d 1132, 1137-38 (1938) (dissenting opinion).

12. This ambiguity has been occasionally recognized, and it has been suggested that the criteria of fitness may be manipulated by the courts to achieve desired results. See Johnstone, stipra note 9 , at 44.

13. "Where the issue is fitness, the character, behavior and circumstances of particular individuals provide boundaries ... with respect to which rational decisions can be made ... . [without] arbitrary or personal decision." Giacopelli v. Florence Crittenton Home, 16 I1l. 2d 556, 567, 158 N.E.2d 613, 619 (1959) (concurring opinion). See Jackson v. Jackson, 164 Kan. 391, 399-400, 190 P.2d 426, 432-33 (1948) ; Bronson, Custody on Appeal, 10 Law \& Contenr. Prob. 737, 740 (1944).

14. In applying the best interest test the trial court has wide discretion because of its unique ability to view the parties, to weigh demeanor evidence, and to utilize psychological insight. E.g., Devlin v. Huffman, 139 Colo. 417, 339 P.2d 1008 (1959) ; Taylor v. Taylor, 182 Okla. 11, 75 P.2d 1132 (1938).

Additional flexibility is introduced into the best interest test, since the various criteria have no predetermined order of importance. Thus any judge considering a particular fact situation might choose to weigh the evidence in a different manner. See the various opinions written in In the Matter of Jewish Child Care Ass'n v. Sanders, 9 Misc. 2d 402, 172 N.Y.S.2d 630 (1957), aff'd, 6 App. Div. 2d 698, 174 N.Y.S.2d 335 (1958), aff'd, 5 N.Y.2d 222, 156 N.E.2d 700 (1959). Cf. Brown v. Brown, 218 Ark. 624, 238 S.W.2d 482 (1951).

15. E.g., Children's Aid Soc'y v. Davis, 211 Ala. 344, 100 So. 325 (1924) (abandonment and comparative physical environments); Coulter v. Sypert, 78 Ark. 193, 95 S.W. 457 (1906) (affection of child toward competing parties, and financial means). Emmer- 
factors, the tendency of the courts to emphasize different factors in each case, and the failure to adopt procedures designed to aid this factual inquiry and thus to fulfill the expressed concern for the child, has led to some feeling that the test may be unworkable or a mere cloak for the operation of judicial intuition. ${ }^{16}$ Whether as a result of these feelings ${ }^{17}$ or because of a sympathy for parental emotions, most courts applying the best interest test to third party situations utilize a variety of procedural devices which increase the probability of the natural parent winning the suit. In effect, the courts seem to have created a continuum from a neutral determination of the best interest of the child to a disguised application of the parental right doctrine. ${ }^{18}$ Colorado son v. Quinn, 79 Idaho 358, 317 P.2d 344 (1957) (physical environment) ; Risting v. Sparboe, 179 Iowa 1133, 162 N.W. 592 (1917) (age, health and sex of the child); Cummins v. Bird, $230 \mathrm{Ky} .296,19$ S.W.2d 959 (1929) (preference of the child, age of the child and maintaining stability) ; Ross v. Pick, 199 Md. 341, 86 A.2d 463 (1952) (maintaining stability and preference of the child); In re Day, 189 Wash. 368, 65 P.2d 1049 (1937) (moral character of the parent and love of both parties for the child).

Few courts have tried to give some order of importance to these criteria, although an occasional attempt has been made. Ross v. Pick, 199 Md. 341, 86 A.2d 463 (1952). Cf. Nye v. Nye, 343 I1l. App. 477, 99 N.E.2d 574 (1951). See note 11 supra. But, again, the commentators have pursued this task with abandon; e.g., Lyon, Azvarding Custody of Children in Illinois-Review of the Factors Considered by the Courts, 11 DE PAUL L. Rev. 42 (1961) ; Note, 38 Minn. L. Rev. 623 (1954) ; Brown, The Custody of Children, 2 IND. L.J. 325 (1927).

16. The test followed here, if it is a test in any sense of the word, does not gain meaning by mere repetition. ... [It] affords little in the way of a guide. . . . [T] he range of inquiry is virtually unlimited. ...

Giacopelli v. Florence Crittenton Home, 16 I1l. 2d. 556, 567, 158 N.E.2d 613,619 (1959) (concurring opinion).

What is for the best interests of this child? In answering such a question judges feel their inadequacy. ... The first consideration is the well-being of the child. . . . But are there no other criteria?

In re Jackson, 164 Kan. 391, 399-400, 190 P.2d 426, 432-33 (1948).

- But, in using the word "test" are we not simply pretending that there is some magic formula that will open the eyes of the court ... ? After studying the material ... it is the author's opinion that no such magic formula exists. Certainly the courts will continue to state their conclusions as . . following some "test."

Bronson, Custody On Appeal, 10 Law \& Contearp. Prob. 737, 742-43 (1944). See notes 14 and 15 supra and accompanying text.

17. "But are there no other criteria? . . . There is one other ... however. If one of the parties is a parent that person has a prima facie right and obligation to the custody." In re Jackson, supra note 16, at 400, 190 P.2d at 433. Occasionally this problem with the best interest test is seized upon as an excuse to abandon the best interest test in favor of the parental right doctrine. See Giacopelli v. Florence Crittenton Home, supra note 16 , at 567,158 N.E.2d at 619 .

18. The most common device has been the presumption that custody by the biological parent will be in the best interests of the child. See, e.g., Risting v. Sparboe, 179 Iowa 1133, 162 N.W. 592 (1917) ; In re Jackson, 164 Kan. 391, 190 P.2d 426 (1948); Ross v. Pick, 199 Md. 341, 86 A.2d 463 (1952). Other courts, while not stating the presumption as such, achieve the same result by holding that other factual considerations must overcome the natural parental right. See, e.g., McDonald v. Short, 190 Ind. 338, 130 N.E. 536 (1921) ; In re Day, 189 Wash. 368, 65 P.2d 1049 (1937). The effect of this presumption is, in large part, only procedural as the likelihood of the third party not producing 
courts, for example, utilize the rebuttable presumption that custody by the natural parent will be in the best interest of the child. ${ }^{19}$

Historically, the parental right test seems to have evolved from doctrines which regarded only the parents' interests in custody matters. ${ }^{20}$ Growing concern for the welfare of the child in custody situations and the disappearance of the concept of the child as property led to a gradual modification in judicial attitude and approach. ${ }^{21}$ Thus, the parental right doctrine is sometimes justified today through the assumption that a natural parent will most adequately fulfill his child's needs. ${ }^{22}$ The best interest test, in turn, seems to have developed from this same impetus to consider the welfare of the child, and the presumption in favor of the natural parent found in the best interest test is often justified by the same generalization-that custody by a biological parent will best achieve the goal of protecting the child's interests. ${ }^{23}$ Although it is

evidence on the issue of best interest is remote. See Ross v. Pick, supra; James, Burdens of Proof, 47 VA. L. Rev. 51, 59-61, 64-65 (1961). A second procedural device used by some courts in conjunction with the presumption mentioned is to shift the persuasion burden to the third party on the issue of best interest, vel non. See, e.g., Ross v. Pick, supra at 351, 86 A.2d at 468; Commonwealth ex rel. Miller v. Barclay, $96 \mathrm{~Pa}$. Super. 315, 318 (1929) ; Sweeney v. Joneson, 75 S. Dak. 213, 216-17, 63 N.W.2d 249, 251 (1954). Finally, several courts have raised the level of proof on the issue of best interest, and thus, further increased the burden of the third party. See, e.g., Judd v. Van Horn, 195 Va. 988, 996, 81 S.E.2d 432, 436 (1954). These procedural devices do, of course, have some substantive effect and their cumulative result is to render the litigation burden of the defending party more difficult. See James, supra at 54-55, 61. Cf. ThaYer, EviDENCE $336-37$ (1898).

Since a presumption, as well as the other mentioned procedural devices, is a method of altering the substantive law in a given area, the common use of the presumption in custody cases would indicate that the courts were not actually. applying a "neutral" best interest test, but rather a version closer in result to the parental right doctrine. See Maguire, Evidence: Common Sense and Common Law 185-86 (1947); Thayer, op. cit. supra 315-35. The degree to which a given court utilizes these procedural devices would determine how close the actual law is to either end of the continuum. Thus if no such device were used, the applied law might be termed a "neutral" best interest test. If the presumption, the shift in the persuasion burden, and the raised level of proof were all used, the resulting law would be virtually indistinguishable from the parental right doctrine.

19. Root v. Allen, 377 P.2d 117, 120-21 (Colo. 1962). This is probably the most common procedural device utilized in the third party situation.

20. See Eyre v. Countess of Shaftsbury, 2 P. Wms. 103, 24 Eng. Rep. 659 (Ch. 1722) ; Ex parte Hopkins, 3 P. Wms. 152, 24 Eng. Rep. 1009 (Ch. 1732) ; Blissets Case, Lofft 748, 98 Eng. Rep. 899 (K.B. 1774); Sayre, Awarding Custody of Children, 9 U. Chr. L. Rev. 672-79 (1942); Note, 42 Harv. L. Rev. 112 (1928).

21. See, e.g., United States v. Green, 26 Fed. Cas. 30 (No. 15256) (C.C.R.I. 1824) ; Wilson v. Mitchell, 48 Colo. 454, 111 Pac. 21 (1910); Chapsky v. Wood, 26 Kan. 650 (1881) ; Sayre, supra note 20, at 672-79.

22. See, e.g., Newby v. Newby, 55 Cal. App. 114, 116, 202 Pac. 891, 892 (1921); Stout v. Stout, 166 Kan. 459, 464, 201 P.2d 637, 641 (1949); In re Kailer, 123 Kan. 229, 231, 255 Pac. 41, 42 (1927); Comment, 33 Calif. L. Rev. 306, 310 (1945). Cf. Lamar v. Harris, $117 \mathrm{Ga} .993,997,44$ S.E. 866,868 (1903).

23. For the historical development of the best interest test see cases cited in note 21 supra. For explanations and justifications of the presumption see, e.g., Wilson v. Mitchell, 
possible that some notion of "parental right" in its original sense survives in these tests as applied and although the two tests will not in each case lead to identical results, ${ }^{24}$ they may fairly be said to seek the same basic goal-protection of the child through a concern with his welfare and environment. ${ }^{25}$ Most recent decisions seem to reflect this operative dominance of the child's interest and welfare. Thus, judges are not only vocally conscious of their special responsibility to the child, but also express this concern more concrete$1 y$ : by refusing to honor biological relationship when the natural parents seem less capable of providing for the child's well-being than the third party. ${ }^{28}$

Implementation of this value choice-to maximize the interest of the childseems the proper goal for custody disputes. The choice between the possibility of harm inflicted upon a mature, responsible adult and a developing, helpless child seems a clear one. ${ }^{27}$ And the judge, the representative of the state as parens patriae, is responsible for guarding the interests of the child before him and thus, in a sense, for representing the child. ${ }^{28}$

48 Colo. 454, 465-68, 111 Pac. 21, 26 (1910) ; Risting v. Sparboe, 179 Iowa 1133, 1136, 162 N.W. 592, 594 (1917) ; Commonwealth ex rel. Miller v. Barclay, 96 Pa. Super. 315, 318 (1929).

24. The clearest indication that vestiges of the supremacy of the parental interest still remain in current law is the procedure used in child custody cases. Thus, although ostensibly the child's interest is sought, he is officially unrepresented at trial. The contending parties, whose interests are allegedly subordinate, have full control over all phases of the litigation: choice of attorney, choice of forum, choice of witnesses, choice of criteria to be applied, and choice of settlement. The old parental right concepts may also be glimpsed in an occasional opinion filed by a state court normally committed to the best interests of the child doctrine. See, e.g., In the Matter of Jewish Child Care Ass'n v. Sanders, 5 N.Y.2d 222, 156 N.E.2d 200 (1959). And several states still retain the parental right test in its un-rationalized form, merely declaring that the parents' interest is superior. See, e.g., Shea v. Shea, 100 Cal. App. 2d 60, 223 P.2d 32 (1950); Roche v. Roche, 25 Cal. 2d 141, 152 P.2d 999 (1944); Stout v. Stout, 166 Kan. 459, 20 P.2d 637 (1949).

Assuming the natural parent to be fit, he would be entitled to custody under the parental right doctrine. However, if the best interest test were applied, the court might reach a contrary result in the same case if it felt that the welfare of the child required the third party to continue custody. See, e.g., Root v. Allen, 377 P.2d 117 (Colo. 1962); Risting v. Sparboe, 179 Iowa 1133, 162 N.W. 592 (1917).

25. See, e.g., Newby v. Newby, 55 Cal. App. 114, 202 Pac. 891 (1921) (parental right doctrine); Wilson v. Mitchell, 48 Colo. 454, 111 Pac. 21 (1910) (best interest test); Risting v. Sparboe, supra note 24 (best interest test); In re Kailer, 123 Kan. 229, 255 Pac. 41 (1927) (parental right doctrine). Cf. State v. Dade, 14 Utah 2d 47, 376 P.2d 948 (1962).

26. See, e.g., Devlin v. Huffman, 139 Colo. 417, 339 P.2d 1008 (1959); Giacopelli v. Florence Crittenton Home, 16 I11. 2d 556, 158 N.E.2d 613 (1959); Trenton v. Christ, 216 Md. 418, 140 A.2d 660 (1958); Merchant v. Bussell, 139 Me. 118, 27 A.2d 816 (1942).

27. While adults might have legitimate interests in the child, selfish ones should be discounted in the manner of Solomon, and selfless ones, ideally, would be reflected in answer to the query: What disposition is in the best interests of the child? While Solomon's test was not stated in terms of best interest, it was clearly designed to separate the selfish concerns of the contending women from the selfless ones and to award custody on that basis. See 1 Kings, $3: 16-28$.

28. See note 3 supra. Moreover, as analysis demonstrates, by maximizing the interests of the child and awarding custody on this basis, the interests of that contending party 
Optimum custody goals may be further defined by concentration on the psychological well-being of the child, where "psychological well-being" is used to denote the mental and emotional health of the child-specifically, a process of personality development within the framework of patterns of normal growth as posited by the behavioral sciences. ${ }^{29}$ In view of the importance of childhood development to the personality structure of the individual, personality disturbances would be more likely if the child's psychological well-being were given only secondary consideration in determining custodial disposition. ${ }^{30}$ In the face of such harm, any material advantages sought in the custody decree, such as maximization of financial means or provision of a superior physical environment, would seem to be of little value. Concern for the psychological, in contrast to physical or material, welfare of the child is implicit in several of the criteria sometimes referred to in connection with the best interest testthose concerned with the love between the child and the parties, the effects of the disruption of existing relationships, and the character and personality of the competing parties. This concern indicates an awareness on the part of some courts of the desirability of allocating custody primarily in terms of the child's psychological best interest in order to achieve the goal of maximization of the child's welfare. ${ }^{31}$

But the incidence of such concern under current practice is so rare that, in terms of the optimum custody goal here assumed, the custody doctrines presently applied in third party situations must be found wanting. Both the parental right doctrine and the procedural devices favoring the natural parent are

with the highest emotional attachment to the child will also be protected in the usual case. Thus the proposed test in a sense will also protect certain adult interests. See note 53 infra and accompanying text.

29. This is not to imply that a so-called "norm" of behavior is required, but only that the child's mental processes on both the conscious and unconscious levels develop so as to permit the child to function as an individual within our society.

The term "psychological best interest" is meant to describe that custodial disposition which probably would most further the child's psychological well-being and personality growth. An alternative phrasing of this concept would be in terms of the least psychological detriment to the child. This alternative would convey the fact that the custody dispute itself, regardless of its solution, would have some effect on the child's mental processes and development, probably a deleterious one. The least detriment concept might also be more consonant with the major trend of psychiatric research and theory which concerns itself primarily with abnormalities in personality development and their cure, rather than with the healthy personality. But since the law of child custody is commonly phrased in terms of best interest of the child, it seems more appropriate to continue using this term, merely modifying it in an effort to separate those factors and criteria considered crucial to achieve the desired goal of maximizing the child's interests.

30. See notes 43-47 infra and accompanying text.

31. See, e.g., Coulter v. Sypert, 78 Ark. 193, 95 S.W. 457 (1906) (affections of child and moral character of parents); Trenton v. Christ, 216 Md. 418, 104 A.2d 660 (1958) (effects of separation); Ross v. Pick, 199 Md. 341, 86 A.2d 463 (1952) (development and happiness of child, affection toward third party, and effects of separation on child's personality growth); State ex rel. Rys v. Vorlieck, 229 Minn. 497, 40 N.W.2d 350 (1949) (psychological disturbances caused by change in custody); Ex parte Day, 189 Wash. 368, 65 P.2d 1049 (1937) (character of natural parent). 
defensible in these terms only by an intuitive but incomplete psychological generalization 32 -that a "blood tie" between parent and child will eventually result in.more and better love and, hence, in a more adequate psychological development of that child. ${ }^{33}$ The principal flaw in the generalization is that it entirely overlooks the child's present structure of relationships. The mutual interaction between adult and child, which might be described in such terms as love, affection, basic trust, and confidence, is considered essential for the child's successful development, and is the basis of what may be termed psychological parenthood. It is this psychological parenthood, rather than the biological events which may precipitate such a relationship, which many psychologists identify as the sine qua non of successful personality development. ${ }^{34}$ While, at birth, a biological parent's potentiality for establishing such a relationship may be greater, no such imbalance exists after a third party has had custody for a period of time. ${ }^{35}$ After a period of separation from the biological parent and care by a third party, the child may learn to look upon the latter as his psychological parent; any prior relationship with the biological parent may deteriorate to the point where it is not only supplanted, but also

32. The intuitive nature of this generalization is apparent in the language of many of the courts. See, e.g., Lamar v. Harris, 117 Ga. 993, 997, 44 S.E. 866, 868 (1903) ("those ties which, by the inscrutable providence of God, bind man to his own flesh."); Risting v. Sparboe, 179 Iowa 1133; 1136, 162 N.W. 592, 594 (1917) ("ties of nature, "bone of their bone and flesh of their flesh." ); Ex parte Day, supra note 31, at 382, 65 P.2d at 1055 (1937) ("the ties of blood should not be interfered with . ...").

33. See, e.g., Chapsky v. Wood, 26 Kan. 650, 652 (1881); Weinman, The Trial Judge Awards Custody, 10 LAw \& Contensp. Prob. 721, 729 (1944).

34. See, e.g., Interviews with Dr. Anna Freud, April 19 and 23, 1963, on file at the Yale Law Journal [hereinafter cited as FreUn InTERviews]; Erikson, Growoth and Crisis of the "Healthy Personality" in Personaltry In Nature, Soctety and Culture 185-225 (1955) [hereinafter cited as ERIKSON]; Freud, Some Remarks on Infant Observation, 8 Psychoanalytic Study of the Child 9 (1953); see generally Bowlby, Child Care AND the Growth of Love (1953).

According to Dr. Freud, without a psychologically adequate relationship between the child and the adult, the adult could not substantially further the child's well-being by aiding his psychological development or assisting in the resolution of personality crises.

Erikson's description of personality development, although couched in different terms, also makes this psychological relationship the foundation of successful personality development. For Erikson the basic component of a healthy personality is the emotional state of basic trust which he defines as "... an attitude toward oneself and the world. . . . [of] trustfulness as far as others are concerned. and a simple sense of trustworthiness as far as oneself is concerned." ErIKson 190. This emotional state is the basis of the child's relationship. with his parents and, in turn, is founded in the child's early experiences with those around him. It is the mutual interaction of parent and child and it is the emotional state which pervades the relationship between parent and child. ERIKson 190-97. It is for this reason that Erikson has said:

$[\mathrm{P}]$ sychiatrists, obstetricians, pediatricians, and anthropologists ... vould agree that the firm establishment of enduring patterns for the balance of basic trust over basic mistrust is the first task of the budding personality and therefore first of all a task for maternal care.

Id. at 195.

35. Freud InTERVIEWS. 
incapable of resuscitation..$^{36}$ Where this has happened, a change in custody based solely on biological relationship might, by disrupting the existing relationship of psychological parenthood, work considerable emotional harm upon the child; it could even cause him to refuse to enter a new relationship. ${ }^{37}$ Thus, the intuitive generalization, by not accounting for present relationships, fails to provide for the child's best interest in maximal fashion. And even a "neutral" best interest test, if applied in the present unstructured manner, would likely fail to establish the requisite psychological best interest because of the test's breadth of inquiry, fluidity of criteria, and consequent submersion of relevant data. ${ }^{38}$

36. Freud Interviews; Burlingham \& Freud, AnNual Report of a Residential WAR NuRSERY 40-42 (1942). In effect, the shorter the child's memory span and the longer the length of separation the less likely it will be that the child is capable of maintaining an inner image of the biological parent.

Moreover, since a child lives primarily in the present, following a radical alteration in his environment-the death of a parent or a change in custody-he will probably form new relationships with adults around him. As these new ties are built, the child's memory of his old "parents" will slowly fade and lose significance. Thus, after living in a nursery away from their parents for several months, children considered the nursery home. BurLIngHaMr \& Freud, supra at 32-47. This is not to say, however, that the child would be incapable of forming a new relationship with the biological parent, but only that the old relationship would be effectively ended sometime following the original separation of the child and biological parent.

37. See notes $43-47$ infra and accompanying text.

38. The unstructured nature of the best interest test and the resulting fluidity of the applied criteria might lead to the ignoring or minimizing of any psychologically relevant data produced at trial. See notes 14, 16 and 17 supra and accompanying text.

In the third party situation, the most frequently overlooked criteria of psychological significance are the preference of the child, the importance of the affections and attachment of the child toward the third party, and the possible effects of a disruption of this relationship. See, e.g., In re Zeigler v. Dusto, 103 Kan. 901, 903, 176 Pac. 974, 975 (1918) ("a parent cannot be deprived of his child because others love her . . ."); Schneider v. Hasson, 161 Md. 547, 157 Atl. 739 (1932) (effects of separation and importance of the love of child rejected); Woodall v. Alexanđer, $107 \mathrm{Kan} .632,193$ Pac. 185 (1920) (affection of child not considered); $c f$. Ludlow v. Ludlow, 89 Cal. App. 2d 610, 201 P.2d 579 (1949) (change of custody so that second parent might have pleasure of the child's company); Kreutzer v. Kreutzer, 226 Ore. 158, 160, 359 P.2d 536, 537 (1961) ("I am not going to call them in and ask them what they [the children] think. . . " per trial court); but see Cummins v. Bird, 230 Ky. 296, 19 S.W.2d 959 (1929) (will consult preference of the child) ; Trenton v. Christ, $216 \mathrm{Md}$. 418, 140 A.2d 660 (1958) (will not disturb established relationships).

Among the psychologically irrelevant criteria sometimes considered by the courts are the race, politics and religion of the parties; the financial abilities of the parties; and the moral character of the parties. See, e.g., Ex parte Adams, 67 Okla. 96, 168 Pac. 1004 (1917) (father's character was "deficient in appreciation of the higher, nobler sentiments of life ..."); People $e x$ rel. Portnoy v. Strasser, 303 N.Y. 539, 104 N.E.2d 895 (1952) (race as an issue); Commonwealth ex rel. Settlemire v. Stephens, $127 \mathrm{~Pa}$. Super. 188, 193 Atl. 80 (1937) (superior financial means of the third party) ; cf. Eaton v. Eaton, 122 N.J. Eq. 142, 191 Atl. 839 (1937), affirming decision reported in N.Y. Times, Jan. 30, 1936, § 1, p. 1, col. 4 (mother was "thoroughly imbued with Communistic, Atheistic and I.W.W. doctrines .. .") ; noted in 49 HARV. L. REv. 831 (1936) ; 36 ColuM. L. REv. 678 
Further inquiry should be made into the fundamental relationship between "psychological" parent and child, here called the "affection-relationship. ${ }^{39}$ The first such relationship, as described in psychological literature, ordinarily arises during the first year of the child's life. It appears to stem from the satisfaction by the "parent" of the child's basic needs for nutrition, warmth, and affection, and it usually continues to develop through childhood and adolescence, thereby teaching the child to regulate his desires and cope with his environment. ${ }^{40}$ The affection-relationship is believed to be the prototype for all future interpersonal relationships, and through its development teaches the child how to form relationships with others. If the affection-relationship is inadequate, future relationships may be lacking in stability, depth, continuity, and trust. ${ }^{41} \mathrm{~A}$ sound affection-relationship is also considered essential for the

(1936). See generally Friedman, The Parental Right to Control the Religious Education of the Child, 29 HARv. L. Rev. 485 (1916). Psychologists and psychiatrists generally consider these criteria of minimal importance in determining the quality and potentiality of the child-rearing situation. As long as certain minimum standards are met in the environment (adequate nourishment, clothing, and shelter), the environmental criteria lack real importance as far as the psychological well-being of the child is concerned. The same is true of the behavioral standards of the adult (morality, religion, and politics). FREUD INTERVIEWS. See generally ERIKSON 185-225. Due to these inadequacies in current legal doctrines, the final decision in any given third party custody dispute will coincide only accidentally with the actual psychological best interest of the child. Thus, neither doctrine can be said to achieve consistently and rationally the desired goal of protecting the child's psychological well-being.

39. See notes 34-37 supra and accompanying text.

40. Freud Interviews; Freud, Some Remarks on Infant Observation, 8 Psychoanalytic Study of tere Child 17-19 (1953).

While at first the mother is regarded by the child from a purely selfish point of view, as the satisfier of his basic needs, this relationship is slowly transformed into one based on love and affection.

The simplest and earliest social modality is "to get," ... in the sense of . . . receiving and accepting ... he learns to regulate his readiness to get with the methods of a mother ... in thus getting what is given ... the baby also develops the necessary groundwork to get to be the giver. ...

ERIKSON 192.

Although the relationship begins in the child's first years its importance never diminishes; it is, in a sense, the keystone of all future development and growth. See generally ERIKSON 185-225.

41. See Freud, supra note 40, at 17-19; FREUd InreRvLews; ERIKson 190-97; BowLBY, op. cit. supra note 34 , at 50-54.

The lack of steady love-relationships in early childhood either by internal or external factors (such as the loss of parents or their substitutes . . .) gives rise to states of emotional starvation with consequent retardation or complete stunting of the child's erotic development. In such cases the normal fusion between the erotic and destructive urges can not take place and aggression manifests itself as pure, independent destructiveness.

Freud, Notes on Aggression, 13 Bull. Menninger Cimic 150-51 (1949).

The future interpersonal relationships of a person deprived of an affection-relationship will be marked by their shallowness and promiscuity. They will be easily formed and easily broken. In essence, the individual will never progress from his childish pattern of self-centered and inconsistent infantile relationships, or if he is able to progress, the 
child's successful resolution of the various internal crises in his personality development. ${ }^{42}$ Thus an affection-relationship's adequacy might be measured by the degree to which it enables the child to proceed with his personality development and to create and maintain satisfactory interpersonal relationships.

The trauma of separating a child from the custody of an adult with whom an affection-relationship exists may be psychologically equivalent in its detriment to the orphaning of that child. ${ }^{43}$ While, in all probability, the child will eventually form a new affection-relationship, this tie may be of lesser quality and strength. And a series of separations might have a cumulative effect on the child's ability to form new affection-relationships. ${ }^{44}$ Where a third party

danger of regression will always be present. His only concern will be with his own needs and wants. Freud, supra note 40, at 17-19. The most serious consequence of a failure to maintain an adequate affection-relationship based on basic trust would be the development of a psychosis stemming from a "basic mistrust." See ERIKSON 190.

42. FREUd InterviEws. For example, the affection-relationship is one of the key factors in the development of the super-ego. This personality structure depends upon an identification with the parent by the child. But lacking an affection-relationship no identification can take place, and an adequate super-ego can not be formed. BuRLINGHAM \& Freud, Infants Without Fammies 102-06 (1944). See generally ERIKson 190-225.

43. Thus the child's psychological reaction to the separation would be identical to his reaction had the adult with whom the relationship existed died. FREUD INTERVIEWs; BuRLinghaM \& Freud, op. cit. supra note 36 , at 32-47. The reaction of a child to such a separation will be most severe between the ages of two and five. Ibid.; ERIKșon 202.

If the child is quite young the effects of separation will probably not be as severe.

[C] hanges, if they have to happen, may be less detrimental in the first six months of life when relationships are based on the fulfillment of physical rather than emotional needs. What exists at that time are the beginnings of an affection-relationship rather than the relationship itself. Consequently, a change in custody may be less detrimental at this time of life than at the next stage.

Letter from Dr. A. Freud to the Yale Law Journal, May 13, 1963, on file in Yale Law Library. Other authorities might disagree with this statement and contend that no matter how young the child, a change in custody and a disruption of existing affection-relationships would be psychologically detrimental. FREUD INTERVIEWS:

On the other hand, as the child grows older the detriment from a disruption of the existing affectional ties would be mitigated by the increased resources and available defenses possessed by the child. But in any event, no matter the age of the child, some psychological scar would be caused by such orphaning. Ibid.

44. Since a child needs an affection-relationship, and since he has a relatively short memory span, a new relationship will probably be formed. But this affectional tie will be farther removed from a mature form of selfless love, and will affect the child's later interpersonal relationships. This lessening of quality of the relationship may stem from the feelings of rejection and resentment by the child. Freud InTERviews; BuritsGe aMr \& FREUd, op. cit. supra note 36 , at $32-47$; see generally FreUd, SAFEGUARding the Emotional Heatth of our Childonen (1955).

Since the quality of the relationship will probably decrease with every "orphaning" the end result of several separations might be the complete inability of the child to form any affection-relationship. Such a result would preclude the child from forming mature interpersonal relationships with others. See $i d$. at 12 . The eventual outcome of this in- 
has custody of a child, the child will probably have already undergone at least one separation trauma. If a new affection-relationship has been formed with the third party custodian, court enforcement of a further change in custody may, by effecting this new separation, markedly diminish the child's willingness or ability to form new relationships, and thus substantially curb his development. And to the extent that such changes may impede the resolution of conflicts arising from the child's present state of development, their effects may be all the more serious. ${ }^{45}$ In Sharon's case the chain of events preceding the attempted reallocation of custody involved four separations. ${ }^{46}$ As the extensive psychological testimony in the Root trial showed, even the prospect of change was sufficient to measurably increase Sharon's feelings of insecurity. ${ }^{47}$

This information suggests the form which a psychological best interest test might take. Its primary aim would be to identify and describe the existing affection-relationship (s), chiefly from the perspective of the particular child who is the subject of the custody dispute. Such relationships might be inferred from evidence shedding light on three questions: the continuity of the relationship between child and adult in terms of proximity and duration; the love of the adult toward the child; and the affection and trust of the child toward the adult. is the subject of the custody dispute. Continuity may provide a basis for inferring that an unbroken relationship of warmth and affection has existed over a period of time sufficient to have established a secure relationship with the adult. ${ }^{48}$ Even if the duration and proximity have been broken an affectionrelationship may be inferred to exist to the extent that the child's memory of the prior relationship enables him to derive some degree of present value from

ability to form interpersonal relationships might be a psychosis characterized by complete withdrawal. See ERIKson 190; Freud Interviews.

45. See notes 43-44 supra and accompanying text. For example, after a change in custody a five year old boy might believe his former psychological parent to be dead as a result of his oedipally oriented death wishes. This guilt feeling might, in turn, lead to serious personality disturbances. See BurLinghaAr \& FreUd, op. cit. supra note 36, at $32-42$.

46. Prior to the custody dispute a child in the third party situation will already have suffered one such trauma when separated from the biological parent(s). If the dispute occurs after the death of a natural parent, as in: Sharon's case, there will have been added the trauma occasioned by that parent's death. A psychiatrist testified in Root v. Allen, 377 P.2d 117 (Colo. 1962), that Sharon had, in fact, undergone four separation traumas -the divorce, the separation of Mr. and Mrs. Allen, Rachel Allen's death, and the death of an expected sibling. See Record, ff. 237-39.

47. See Record, ff. 243-49.

48. Without this necessary continuity of relationship a new affectional tie can not be formed by the child with the third party. Freun InTERviEws. Thus, the existence, or lack thereof, of this factor would be a ready and fairly accurate indication of the quality of the relationship existing between the third party and the child. If the child had been in the care of the third party for a long period of time (three years, for example), it would be likely that an adequate affection-relationship existed. On the other hand had the custodial period been relatively short the opposite would be expected. 
its remembrance. ${ }^{49}$ Secondly, since an affection-relationship is dependent upon reciprocal love, the attitude of the adult toward the child may indicate the quality of their relationship. The quality of the adult's love is better manifested by past and present care and concern for the child than by court room histrionics and shallow demonstrations. The adult's self-appraisal would also be relevant, for, lacking confidence and trust in himself, he would probably be unable to form a viable relationship with the child. ${ }^{50}$ The third and most important basis for inferring an affection-relationship is the child's love for the adult. ${ }^{51}$ While the affection-relationship is an interaction, it need not be equal. From the perspective of the child's best interests, continuity, stability, and love by the adult may be necessary for the formation and maintenance of adequate affectional ties, but the love and trust of the child for the parent is usually considered the predominant factor which determines its quality. ${ }^{\mathbf{5 2}}$

Although a child may enjoy separate affection-relationships with several adults, there will be cases in which the court discovers the existence of only one viable affection-relationship. In these cases, custody disposition under the proposed test will be relatively simple; no further inquiry need be made. Awarding custody to the adult member of this relationship would presumably enable the child to continue his personality development with the continuous,

49. In this sense the length of separation from the natural parent and the age of the child would indicate the continuity and stability of the relationship between the child and that parent. See note 36 supra and accompanying text. Thus, a ten year old child separated from his natural parent for several months might preserve an image of that parent in his mind, and the relationship could be said to have continued. In contrasting such a relationship to an existing third party relationship, a comparison of temporal factors, along with a comparison of the stability of the respective relationships, would enable the relative qualities of the relationships to be measured in a crude fashion.

50. FREUd INTERVIEWS; see ERIKSON 190-97. The evaluation of the adult would, of cuurse, be most accurately made by a competent expert. However, this task might also be performed by a sensitive judge in the absence of psychiatric testimony. The danger inherent in such an evaluation would be, of course, an erroneous conclusion concerning the adult's ability to form or maintain an adequate love tie. FREUD INTERVIEws. In this evaluation by the court, testimony by lay witnesses, as well as the party in question, would be of value. Thus, the court might properly consider as relevant, testimony concerning the adult's treatment and attitude toward the child, i.e., methods and frequency of discipline, interest in the child's activities and development, and concern with helping the child solve his problems.

51. In general, the articulated preference of the child to live with either party would be a reliable indication of where his affectional ties lay. But because of the danger of lack of comprehension or sheer perversity, a younger child would have to be questioned closely on this point. If the interview were conducted tactfully and sympathetically, the results could be treated as psychologically valid. Dr. Freud suggests that a trained psychiatrist or psychologist would have no problem in making such an evaluation. Freun INTERVIEws. In this investigation of the child's attitude toward the adult, the court might also resort to testimony concerning the child's behavior in reference to the adult, i.e., how the child reacted to instructions by the adult, how the child reacted to discipline by the adult, how the child referred to the adult in his absence.

52. FrEUd INTERVIEWS; see ERIKSON 190-97. 
stable support of the existing affectional ties, and would prevent a separation trauma and its consequent effects upon the formation of future interpersonal relationships. ${ }^{53}$ Root $v$. Allen is a prototype of this limited case.

At the time of the trial expert testimony indicated that Sharon was a quiet, reserved and shy pre-adolescent, lacking confidence in herself and her environment, who because of her pronounced insecurity continually sought to form solid attachments with those around her. ${ }^{54}$ Following her mother's death, Allen represented the one meaningful and stabilizing adult figure in her life: even during her mother's lifetime, Sharon's affection-relationship with Allen was quite strong. Because of this, Allen was described as Sharon's principal link with her previous identities and roles.55 One result of the custody dispute had been to make Sharon apprehensive over her future and confused about her roles within the Allen family, thus rendering her insecurity and need for stability more acute. ${ }^{56} \mathrm{~A}$ number of expert witnesses at the trial testified that were custody to be changed, the destruction of Sharon's affection-relationship with Allen would have increased her feelings of insecurity and instability. ${ }^{57}$ While they agreed that Sharon was likely to form affectional ties within the Root family, they also agreed that these ties would probably not be particularly strong. They also noted that Sharon might have developed feelings of resentment and anger toward Root and toward Allen which might have led to a wider variety of psychological defects. ${ }^{58}$ With the strength and ex-

53. In those cases where custody is allocated in harmony with the exclusive affectionrelationship the adult with the highest emotional involvement with the child will also find his interests protected. See note 28 supra and accompanying text.

54. Approximately one fifth of the testimony at trial (129 pages of the record) was presented by eight expert witnesses, called by both parties. In addition, the majority of the lay witnesses were questioned primarily in regard to Sharon's relationships within the Allen family. Sharon's insecurity was observed by all of the expert witnesses. See, e.g., Record, ff. 186-99, 237-49, 300-06, 343-48; Root v. Allen, 377 P.2d 117, 119 (Colo. 1962). This insecurity was manifested by bed-wetting, and it had been recommended that Allen seek psychiatric assistance for Sharon. Record, ff. 186-91.

55. "[T]he one great stabilizing factor in her life was the relationship with ... Allen. Some of the testimony reveals he is closer to her, . . . than even her mother was." Root v. Allen, 377 P.2d 117, 119 (Colo. 1962). "There was mutual love between the two, and Mr. Allen-even more so than Sharon's own mother-was devoted, understanding, and did everything he could to make her happy. . . ." Id. at 121. See Record, ff. 178-82. "The one person who seems to have stuck by her through thick and thin is her stepfather, Mr. Allen, who seems very much attached to her." Record, ff. 238-39. Sharon also had developed an affectional tie with her new step-mother, and, of course, she also had love ties with her siblings. See Record, at ff. 178, 237-38, 313, 943-48.

56. See Record, at ff. 243-49, 300-06.

57. See Root v. Allen, 377 P.2d at 119-21; Record, ff. 181-99, 240-53, 300-13, 340-48, $943-48$.

58. Record, at ff. 240-41. Only one psychiatrist testified that a change in Sharon's custody was warranted. He seems to have based this opinion largely on the theory that: "She has a right ... to union with, knowledge of, love for her own natural father, and 
clusivity of her present relationship so clearly established, and the possibility of detriment occurring after a change so strong, the Colorado court's disposition seems justified without further inquiry. 59

In the limited case, like Root $v$. Allen, where the child's dependence upon an affection-relationship should be dispositive of the custody issue, the practical requirements for effective decision, even under present procedures, do not seem overly taxing on the court or litigants. Thus, a noted child analyst has remarked that a child's affection-relationship and the strength of his dependence upon it may be evaluated through relatively simple inquiry. ${ }^{60} \mathrm{Al}-$ though it seems preferable for such inquiry to be performed by experts, it may also be within the capacities of a sensitive judge. Since the emphasis in such an inquiry is focused to a great extent upon the child and his perspectives, the distortion induced by selection of the expert witnesses by the adult parties contending for custody may not be great. ${ }^{61}$ And since the field of inquiry is relatively structured, narrow, and simple, difficulties of judicial comprehension and judicial use of expert testimony may also be expected to remain at low levels. ${ }^{62}$ Finally, if courts are willing to use the test for affection-relationships, granting custody to third party adults who have established an exclusive

I think this must not be overlooked." Record, at f. 336. The remaining expert witnesses who testified on the question of what disposition was in the best interests of Sharon agreed that a change in custody would probably be detrimental. See, e.g., Record, at ff. $181-82,253,943-48$.

59. The correctness of this decision is supported by Sharon's subsequent development and adjustment. The Allens sought "professional help for Sharon . . . counselling continued about $11 / 2$ years-has now terminated and Sharon is adjusting very well, improved in many respects." Letter from $\mathrm{H}$. Ted Rubin, Attorney for Robert Allen, to the Yale Law Journal, May 16, 1963, on file in Yale Law Library.

60. See notes $\mathbf{5 0}$ and $\mathbf{5 1}$ supra.

61. In Root v. Allen, 377 P.2d 117 (Colo. 1962), six experts were called by Allen and only two by Root. As would be expected, the testimony of the respective experts generally favored the party who produced him. In all likelihood this disparity in quantity of witnesses merely reflected the fact that in Sharon's case the detriment likely to occur from a change in custody was fairly certain and apparent, so that Root could find few experts he cared to have testify for him. Undoubtedly, this selectivity may present a danger of distortion in the testimony of experts where only one of the contending parties has sought expert opinion. Witness this incident:

The psychiatrist not being amenable to the mother's purpose, his testimony was, of course, not called for in court. The father, an unworldly man ... never realized that expert testimony was buried somewhere which might have been of help to him.

Desfort, Chitdren of Divorce 210 (1953).

62. An additional problem that might arise in many cases is where one or both parties are financially unable or unwilling to provide expert testimony. This possibility is mitigated, however, by the relatively slight degree of psychological assistance required in the limited case of the exclusive affection-relationship. Thus, given sensitivity on the part of the court, the lack of expert testimony can be rectified by judicial inquiry. See notes 50 and 51 sipra. 
affectional tie with the child may have the desirable result of deterring biological parents from subjecting the child to the inevitable detriment of unwarranted litigation. ${ }^{63}$

Of course, in many circumstances more than one viable affection-relationship may be found, or existing relationships may be found substantially wanting as a foundation for the child's future growth. In such a case, analysis in terms of affection-relationships alone might not be sufficient to secure the child's psychological best interests. If more than one viable affection-relationship were found to exist, for example, any disposition would, in effect, entail the possibility of some emotional harm to the child through its effect upon the disfavored affection-relationship. ${ }^{64}$ Although crude quantitative comparison of the degree of harm to expected might be made, it seems possible that, in this case, substantial risks of error might arise through reliance on this factor alone. ${ }^{65}$ Since the fundamental need for an affection-relationship could be satisfied through either possible disposition, it would become relevant to consider the child's psychological best interests in terms of other psychological factors relating to the particular needs of his personality: his current state of development and immediate emotional requirements, and his likely patterns of future development, resulting crises, and probable needs. ${ }^{66}$ Such an inquiry might have been requisite for Sharon, had she been more secure in the prospect of change, or had her insecurity been traceable in part to inadequacies in Allen's fulfillment of parental roles, or had there been an affection-relation-

63. While application of the proposed test will promote the psychological best interest of the child, some emotional detriment would be likely to ensue from the very existence of the dispute and litigation. See note 29 supra.

64. See notes 43-47 supra and accompanying text.

65. In the "normal" case it would be expected that allocating custody in accordance with the "strongest" or "best" affection-relationship would result in the least detriment to the child. Not only would the child be enabled to continue his development with the strongest emotional support available, but also the effects of separation would probably be less severe were the weaker tie to be broken. However, this analysis breaks down as the competing relationships come closer to equality. At this point the possibility of error in measuring quality becomes more significant, and a disposition made on the basis of such comparison becomes riskier in the sense that the child's best interest may not be served. Developmental needs in addition to the affection-relationship might well swing the balance in some cases. And in the case where the affection-relationships are found to be substantially equivalent, no criterion would exist to permit disposition unless other factors were referred to. See notes 67 and 69 infra and accompanying text. (See, FreUd INTERVIEWS).

66. Investigation of the child's personality and needs, current and prospective, would, of course, be in addition to the inquiry into his affection-relationships. What is proposed is that this additional information be evaluated in order to determine whether allocation in accordance with the quality of the existing relationships would indeed further the child's psychological well-being. In this way the danger of faulty quality evaluation or of the exceptional case would be obviated. See note 65 supra. This extensive investigation into the child's personality would, of necessity, require expert psychological assistance; it is to be doubted whether it could be properly conducted even by well-informed laymen. 
ship with Root; in her case it might have centered upon the developmental needs of a child about to enter the stress-filled periods of puberty and adolescence. $^{67}$ Armed with knowledge of the child, his personality, and his existing affection-relationships, a court might then examine the alternative custody dispositions in light of their probable consequences to the child's well-being, and may be able to choose an environment, which, if not psychologically ideal, will result, at least, in minimal harm to the child. ${ }^{68}$

In the limited scope of a Note, it is not possible to do more than suggest the range of problems which can be solved by the proposed "psychological best interest test." The following major questions, at least, still remain unanswered in third party disputes :

67. In an effort to add some content to this proposed test the following tentative and hypothetical consideration of adolescence is offered. This evaluation, offered solely as an example, will only consider the possible effects a change in custody might have upon an adolescent (or pre-adolescent) who has formed a viable affection-relationship with his current custodian. Thus this analysis is only meant to suggest some of the possible factors that might arise in an inquiry into a given adolescent's personality. Moreover, the psychological conclusions reached herein are largely extrapolations made by the writer on the basis of general psychological theory and knowledge.

Adolescence is usually considered a period of severe physiological and psychological stresses for the average child during which he engages in the psychological process described as ego-synthesis, whereby he forms his adult identity. The physiological changes occurring during adolescence are believed to alter radically his drives and desires; he now inspects and evaluates the tentative personality he has developed during his childhood and furms a new "adult" personality. ErIrson 215-21; Freud, Adolescence, 13 PsychoANAlytic Study of the Chind 255 (1958); Geleerd, Some Aspects of Ego Vicissitudes in Adolescence, 9 J. Ans. Psychoanalytic Ass'N 394 (1961). Because of the child's pre-occupation with these problems of identity, many might find it difficult to cope with traumatic experiences, such as a change in custody. See Geleerd, supra at 402-04. Moreover, a change in custody at this time might be detrimental, since the child's pubertal strivings to form a consistent identity are usually facilitated by continuity of relationships within his family, peer groups, and environment. See ERIKson 215-21; Freud, supra at 268-69. A custody change might also prevent or delay a second expected psychological development of adolescence, the child's ability to break his emotional dependence upon his parents, either by causing the child to fixate at the pre-adolescent stage, or by delaying entrance into puberty until the child had formed a secure affectional tie with the new custodian. See Freud, supra at 265-66. Another danger in a change of custody might be the formation of a guilt complex. See Freud, supra at 255-73; Geleerd, supra at 402-04.

However, although the adolescent may have formed a stronger affection-relationship with the third party custodian, nevertheless a change in custody might be called for since inquiry in the individual case may reveal that the child might benefit by such a change. For those whose previous development had been untroubled, a change in custody might cause little psychological detriment if they had relatively mature personalities. FrEUD INTERVIEwS. In such a case a change might also produce some psychological benefit to the adolescent by obviating the resentment and exaggerated rebellion which might stem from the denial of an opportunity to know and to live with the biological parent(s). See Record, ff. 319-22; Freud, supra at 268-75; Geleerd, supra at 401-02. Where the child has an existing affection-relationship with the biological as well as the third party parent, this is especially likely to be true.

68. See note 29 supra. 
1. Where substantially equivalent affection-relationships exist: How may the additional psychological criteria needed for effective decision be structured into the proposed test? Can non-psychological criteria be used consistently with the desired goal of protecting the child's psychological well-being? If so, how can they be integrated into the test? ${ }^{69}$

2. Where no adequate affection-relationship exists: Are other psychological criteria, consistent with those already enunciated, available? Can non-psychological criteria be used consistently with them? How may these additional criteria be integrated into the proposed test?

3. Where one or several parties are mentally disturbed: Should this ever be a factor in disposition? Should the child be automatically awarded to the non-disturbed party? If so, how severe should the disturbance be in order to deny custody? How should this level be recognized and measured? What criteria for disposition should be used in such a case? What community resources are, or should be, available to handle this situation?

4. If non-psychological criteria are to be consulted, what are they and how shall they be weighed? Extreme poverty? Religious or political beliefs? Moral character of the adult? Other social or community policies or objectives (e.g., to discourage increases in farm population, to discourage settlement in chronic depressed areas, to prevent raising children in areas with high incidences of juvenvile delinquency)?

It is also necessary to ask how effectively the suggested standard can be utilized in the more frequent custody dispositions accompanying separation and divorce:

1. Should the same basic value-the maximization of the child's interests and welfare-be the goal of the law, or should the adult interests also be considered? If the best interests of the child is selected as the goal, would this be best achieved by maximization of the child's psychological welfare?

2. If psychological welfare is desired, what psychological criteria should be selected to accomplish this goal? May non-psychological criteria be used consistently with the psychological? If so, what criteria?

3. What, if any, distinctions should be made between custody disputes involving third parties and dispositions in connection with separation or divorce?

These unanswered questions suggest questions in the domain of practicality and procedure for both the third party and the divorce and separation disputes : $\mathbf{: 0}^{\mathbf{0}}$

1. Should the procedures be identical for all custody cases? Is the judge the best possible decisionmaker for child custody disputes? Should he be replaced by a psychiatrist, by a panel of experts, medical, legal, and religious, by a social agency?

69. See note 65 supra.

70. See notes 60-62 supra and accompanying text. The narrow situation in which these procedural problems are minimal should be distinguished from the more difficult 
2. Does the parties' selection of witnesses, expert or otherwise, cause actual or potential distortion of the "facts"? If so, how may such distortion be eliminated or minimized? Does the parties' control over litigation endanger the child's interests, and, if so, how may this be alleviated?

3. Would financial inequality of the parties endanger the accuracy of decision? If so, how might such inequality be rectified?

4. Is an adequate and accurate flow of information to the court insured in all cases by current procedures? Is there a general failure of communication between the court and the expert witnesses? If so, how may this breakdown be alleviated?

5. Is there any danger of wrong decision stemming from incompetent attorney, from improper judicial estimation of the creditibility of witnesses, from lack of judicial comprehension of the proposed best interest test?

6. Are present procedures too dominanted by aduit parties to allow a fair and accurate determination of the child's best interest? Would new procedures help alleviate this possibility, i.e., party status for the child, an advisor or friend of the court to protect the child's interests, a social agency to assist the court, a more active judicial role in the inquiry?

7. What should be the basis and criteria for review of the trial court's decision by a higher court? Should the trial court be afforded any discretion? If so, how should such discretion be effectively limited?

8. Should custody decrees be subject to periodic review to determine whether the disposition has had satisfactory results? If so, should the doctrine of changed circumstances be maintained as a vehicle for such re-examination? What should be the criteria used in this evaluation? Should such an evaluation be made necessary, or should it await some signal event, i.e., a poor adjustment on the part of the child resulting in behavioral or educational problems? 9. Is there any danger of conflict between a psychological best interest test and Neglected Children Statutes, or Family Court Acts?

Failure to resolve these questions, however, does not necessitate postponement of the adoption of the proposed test in the limited area of exclusive affection-relationships. ${ }^{71}$ Moreover, the basic structure of the psychological best interest test which has been presented should enable further, necessary content to be added to the test even where competing affection-relationships exist. The present likelihood of over-stress on parents' interests in third party situations may make conscious emphasis by the court on the child's interests and recognition of the distinction between biological and psychological parenthood particularly important. And in the narrow situation where inquiry is case where identification of the affection-relationship $(s)$ and their quality is not dispositive of the issue. In this latter situation these procedural problems become more serious, and for successful attainment of the desired goal of maximizing the child's interest it would seem necessary that more detailed analysis of their effect be undertaken.

71. See notes $60-62,70$ supra and accompanying text. 
limited by the discovery of an exclusive affection-relationship and where the child's need for its continuance is sufficient for disposition, practical difficulties are minimized by the relatively slight period of time required for expert inquiry and the possibility of competent and sensitive judicial investigation. ${ }^{2}$

72. See notes 53, 60-62 supra and accompanying text. 